\title{
Last instar larva of Microstigmus nigrophthalmus Melo (Hymenoptera, Crabronidae, Pemphredoninae), with notes on biology
}

\author{
Sandor Christiano Buys ${ }^{1}$
}

\begin{abstract}
The last instar larva of Microstigmus nigrophthalmus Melo, 1992 is described. It markedly differs from that of $M$. comes Krombein, 1967 the only other species in the genus whose mature larva have been described, for features as follows: presence of spinnerets; setae on the labrum, maxillae and labium; mandibles with tridentate apex and a bidentate lateral projection; lack of the conical supranal process. Notes on habitat, structure, and content of nests are also presented.

KEY WORDS. Microstigmus nigrophthalmus, sphecoid wasp, morphology, larva, biology, behaviour, Brazil
\end{abstract}

Microstigmus Ducke, 1907 is a Neotropical genus with 29 described species (MELO \& MATTHEWS 1997). This genus seems to be unique among sphecoid wasps in presenting species with eusocial behaviour (MATTHEws 1968). The mature larva of only one species was described in detail: Microstigmus comes Krombein, 1967 (EvANS \& MATTHEWs 1968). Microstigmus nigrophthalmus Melo, 1992 is a recently described species that progressively provision its nests with Cicadellidae nymphs (MELO 1992). Herein the last larval instar of this species is described and biological notes are presented.

The description presented below is based on two last instar larvae collected on the National Park of Floresta da Tijuca, Rio de Janeiro State, Brazil, 3-VI-2000. However, the morphometric features were measured in only one specimen. Others nests were found on the National Park of Serra Órgãos, also in Rio de Janeiro State, January, 2000. The techniques for studying larvae of Apoidea have been discussed by MiCHENER (1953) and EVANS \& LIN (1956). Voucher specimens have been deposited in the collection of Department of the Zoology of the Universidade Federal do Rio de Janeiro.

\section{RESULTS}

\section{Microstigmus nigrophthalmus Melo, 1992}

Last instar larva (Figs 1-5)

Body. Fusiform, white, $7 \mathrm{~mm}$ long and about $1.5 \mathrm{~mm}$ in maximum width (on the thorax). Pleural lobes undistinguished on thorax, small and poorly distinguished on abdomen. Integument smooth, without setae or spines. Spiracles unpigmented, inconspicuous; 20 to $25 \mu \mathrm{m}$ in diameter, enlarging more or less progressively toward the anterior portion of the body.

1) Laboratório de Entomologia, Departamento de Zoologia, Universidade Federal do Rio de Janeiro. Caixa Postal 68044, 21944-970 Rio de Janeiro, Riode Janeiro, Brasil. 

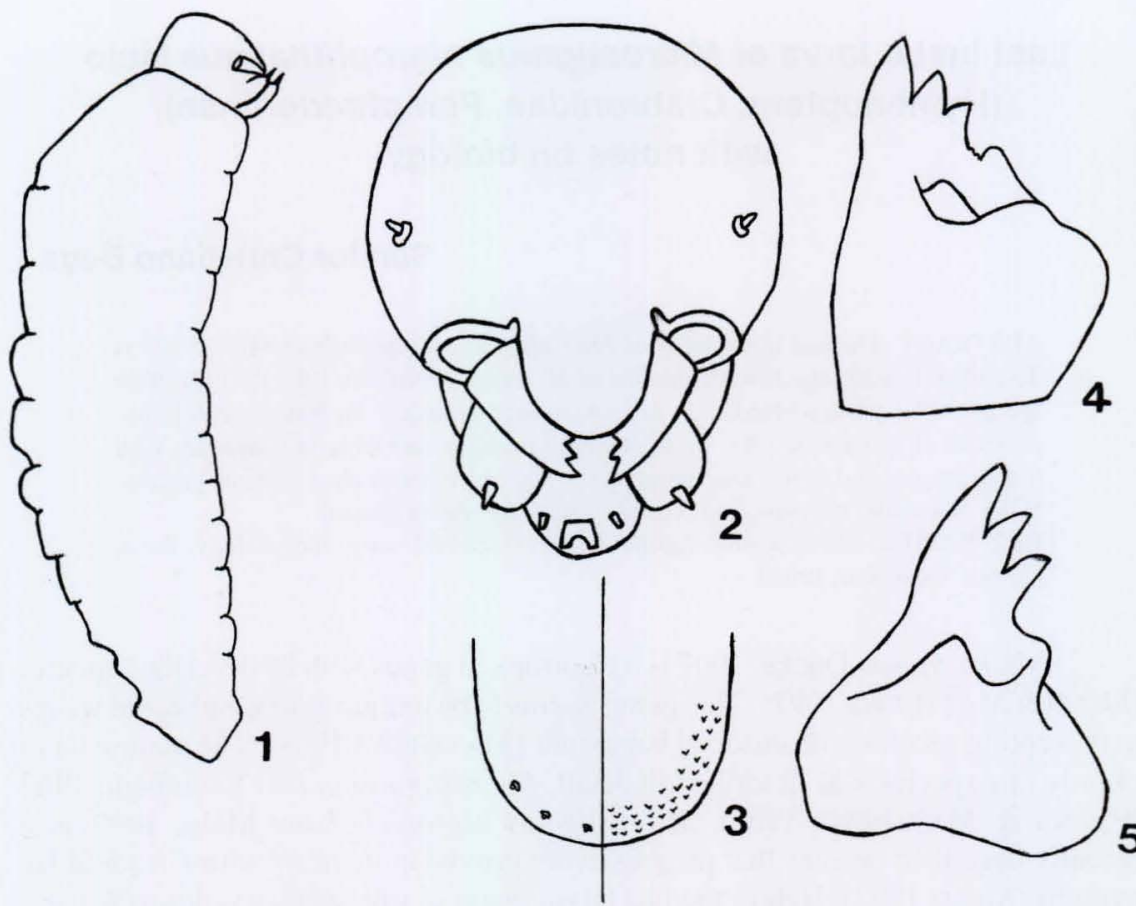

Figs 1-5. Microstigmus nigrophthalmus, last instar larva. (1) Body, lateral view; (2) head, frontal view; (3) labrum and epipharynx, frontal view; (4) mandible as seen in frontal view of the head; (5) dissected mandible, frontal view.

Head. Unpigmented, except for the mandibular teeth, including those on the lateral projection; $570 \mu \mathrm{m}$ wide and $535 \mu \mathrm{m}$ long. Antennal orbits circular, $20 \mu \mathrm{m}$ in diameter; antennal papillae conical, about $38 \mu \mathrm{m}$ long. Parietal bands and coronal suture not visible.

Mouthparts. Labrum semicircular; $55 \mu \mathrm{m}$ in height; with a few sensilla near the margin and scattered setae. Epipharynx with minute spines sparsely distributed on the marginal portion. Mandibles $210 \mu \mathrm{m}$ long and $125 \mu \mathrm{m}$ in maximum width; broad basally, abruptly tapering to a tridentate apex; with a bidentate lateral projection. Maxillae with two setae, each seta about $12 \mu \mathrm{m}$ long; maxillary palpi conical, about $37 \mu \mathrm{m}$ long. Galeae absent, but a pair of small sensilla present in the same position. Lacinial area with small, sparsely distributed spines. Labial palpi conical, about $25 \mu \mathrm{m}$ long. Spinnerets truncate apically, about $30 \mu \mathrm{m}$ long.

Biology. The nests were found suspended under the roof of houses in areas with adjacent Atlantic forest. They consist of a globular sac made of small fragments of wood aggregated with silk. A petiole made of silk alone, with 7-18 mm long (n $=3$ ), attaches the nest to the substrate. More rarely other plant debris, as stamens and leaf fragments, are found on the nest formation. The wasps enter the nest through an oval opening near the base of the petiole. The internal nest surface is coated with 
silk. The bottom is divided in up to ten cells, all of them with about the same size. Prey remains were not found in the cells. The nest found in the National Park of Floresta da Tijuca had the following content: one egg attached to the bottom of the cell; two immature larvae; three last instar larvae; three pupae; and one empty cell.

\section{DISCUSSION}

The mature larva of $M$. nigrophthalmus differs markedly from that of $M$. comes in several features: presence of spinnerets; setae on maxillae, labium and more rarely on labrum; mandibles with tridentate apex and a bidentate lateral projection; a pair of sensilla in the position usually occupied by the galeae in other Hymenoptera; lack of the conical supranal process. The presence of spinnerets in M. nigrophthalmus is surprising, since this species does not spin cocoons. MELO \& EVAnS (1993) comment that the larvae of M. xylicola Melo, 1993 and M. similis Melo, 1993, two closely related species, have spinnerets and spin cocoons. On the other hand, $M$. comes apparently has no spinnerets and does not spin cocoons (EVANS \& MATTHEWS 1968). Microstigmus nigrophthalmus seems to be in an intermediate evolutive stage between the species with functional spinnerets, that spin cocoons, and species without spinnerets. Possibly the spinnerets are not functional in $M$. nigrophthalmus, but it is necessary a biological survey to evaluate the possibility that this species use the spinnerets in activities other than spinning cocoons. EVANS \& MATTHEWS (1968) suggest that the spinulose lobe on the inner margin of the mandibles of $M$. comes may be an adaptation for feeding upon Collembola. In fact, the mandibles of M. nigrophthalmus lack this structure. On the other hand, they have a bidentate lateral projection which may be correlated with the habit of this species feeding upon Cicadellidae.

ACKNOWLEDGEMENTS. I thank Cinara Silva and Marcello Giffoni for helping to collect the wasps and their nests and Márcio Félix, Alexandre Rosas, and two anonymous referees for comments on the manuscript.

\section{REFERENCES}

Evans, H.E. \& R.W. MatThews. 1968. The larva of Microstigmus comes, with comments on its relationship to other genera (Hymenoptera, Sphecidae). Psyche 75 (2): 132-134.

Evans, H.E \& C.S. Lin. 1956. Studies on the larvae of digger wasps (Hymenoptera: Sphecidae). Part I. Trans. Amer. Ent. Soc. 81: 131-153.

Matthews, R.W. 1968. Microstigmus comes: sociality in a sphecid wasp. Science 160: 787-788.

Melo, G.A.R. 1992. Duas novas espécies de Microstigmus Ducke, 1907 (Hymenoptera, Sphecidae). Revta bras. Ent. 36 (3): 663-670.

Melo, G.A.R. \& H.E. Evans. 1993. Two new Microstigmus species (Hymenoptera, Sphecidae), with description of their parasite, Goniozus microstigmi sp. n. (Hymenoptera, Bethylidae). Proc. Entomol. Soc. Wash. 92 (2): 258-263.

Melo, G.A.R. \& R.W. Matthews. 1997. Six new species of Microstigmus wasps (Hymenoptera: Sphecidae), with notes on biology. Jour. Nat. Hist. 31: 421-437.

MiCHENER, C.D. 1953. Comparative morphological and systematic studies of the bees larvae with a key to the families of hymenopterous larvae. Univ. Kansas Sci. Bull. 35: 987-1102.

Received in 03.VIII.2001; accepted in 15. VII.2002. 